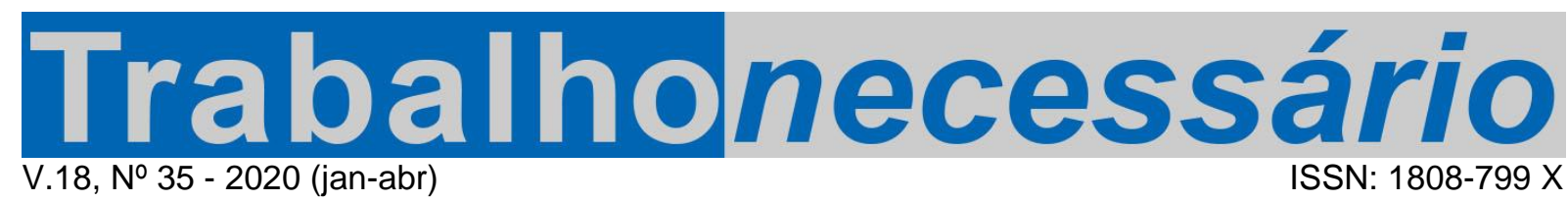

DOI: https://doi.org/10.22409/tn.v18i35.40501

\title{
ESTRATÉGIAS DE CONTROLE DAS CLASSES PERIGOSAS: O ENSINO PROFISSIONAL DO IMPÉRIO À REPÚBLICA ${ }^{1}$
}

\author{
José António Martin Moreno Afonso² \\ Renato Marinho Brandão Santos ${ }^{3}$
}

\begin{abstract}
Resumo
O artigo analisa as diferentes concepções politico-educativas sobre o ensino profissional no Brasil, desde os Liceus e Casas de Educandos, no período imperial, até as Escolas de Aprendizes, estabelecidas nas capitais brasileiras a partir de 1910, durante a Primeira República. Discute, ao longo dos diferentes períodos, a associação entre o ensino profissional e o controle das denominadas "classes perigosas". Especificamente em relação à República, observa o diálogo entre esse regime, que procura se associar às ideias do novo e do progresso, e as Escolas enquanto instituições modernas responsáveis por estabelecer padrões de comportamento e valores. Em conclusão, afirma que os caminhos para consolidação do ensino profissional no Brasil foram tortuosos, tendo como reflexo, entre outros pontos, os altos índices de evasão verificados nas Escolas de Aprendizes.
\end{abstract}

Palavras-chave: História da educação; Escolas de aprendizes; Classes trabalhadoras.

ESTRATEGIAS DE CONTROL DE CLASES PELIGROSAS: EDUCACIÓN PROFESIONAL DESDE EL IMPERIO A LA REPÚBLICA

\section{Resumen}

El artículo analiza las diferentes concepciones político-educativas sobre la educación vocacional en Brasil, desde el Liceo y Hogares de Educandos, en el período imperial, hasta las Escuelas de Aprendices, establecidas en las capitales brasileñas desde 1910, durante la Primera República. Discute, durante los diferentes períodos, la asociación entre la educación vocacional y el control de las llamadas "clases peligrosas". Específicamente en relación con la República, observa el diálogo entre este régimen, que busca asociarse con las ideas de nuevo y progreso, y las Escuelas como instituciones modernas responsables de establecer estándares de comportamiento y valores. En conclusión, afirma que los caminos para consolidar la educación vocacional en Brasil fueron tortuosos, reflejando, entre otras cosas, las altas tasas de deserción que se encuentran en las Escuelas de Aprendices.

Palabras clave: Historia de la educación; Escuelas de aprendices; Clases trabajadoras

\section{DANGEROUS CLASS CONTROL STRATEGIES: PROFESSIONAL EDUCATION FROM THE EMPIRE TO THE REPUBLIC}

\begin{abstract}
The article analyzes the different politico-educational conceptions about vocational education in Brazil, from the Lyceum and Homes of Learners, in the imperial period, to the Apprentices Schools, established in the Brazilian capitals from 1910, during the First Republic. It discusses, over the different periods, the association between vocational education and the control of the so-called "dangerous classes". Specifically in relation to the Republic, it observes the relationship between this regime, which seeks to associate itself with the ideas of the new and progress, and the Schools as modern institutions responsible for establishing standards of behavior and values. In
\end{abstract}

\footnotetext{
${ }^{1}$ Artigo recebido em 11/10/ 2019. Primeira avaliação em 02/11/2019. Segunda avaliação em 12/11/2019. Aprovado em 15/12/2019. Publicado em 23/01/2020.

2 Doutor em Educação - Área de conhecimento em História da Educação pela Universidade do Minho. É docente do Instituto de Educação e investigador do Centro de Investigação em Educação (CIEd) da Universidade do Minho. E-mail: jafonso@ie.uminho.pt Orcid: 0000-0002-7061-306X

${ }^{3}$ Doutor em Educação - Área de conhecimento em História da Educação pela Universidade do Minho. É docente do Instituto Federal do Rio Grande do Norte (IFRN), campus São Gonçalo do Amarante. E-mail: renato.marinho@ifrn.edu.br. Orcid: 0000-0002-8187-7140.
} 
conclusion, he states that the paths to consolidate vocational education in Brazil were tortuous, reflecting, among other things, the high dropout rates found in the Apprentices Schools.

Keywords: History of education; Apprentices schools; Working classes.

\section{O que fazer com as "classes perigosas"?}

Nos meados do século XIX, em boa medida por conta da pressão inglesa (CASTRO, 2000, p. 62), o governo imperial, comandado por Dom Pedro II, deu início ao processo de abolição da escravatura no Brasil, com a Lei Eusébio de Queiroz, responsável por proibir o tráfico negreiro no país. O processo foi concluído, ao menos em parte, em 13 de maio de 1888, data em que a princesa Isabel, como regente do Império brasileiro, assinou a Lei Áurea. Na mente daqueles que compunham a elite brasileira restava, porém, um grande ponto de interrogação: o que fazer com os negros libertos pela Lei Áurea e com sua prole?

Mas de que elite tratamos? Referimo-nos a um grupo social marcado, segundo J. M. de Carvalho, por uma "homogeneidade ideológica e de treinamento" (2008, p. 21) que reduzia os conflitos intraclasse e fornecia a "concepção e a capacidade de implementar determinado modelo de dominação política" (Idem, ibid.), marcado pela exclusão das classes populares da política institucional. Carvalho afirma, ainda, que "essa homogeneidade era fornecida sobretudo pela socialização da elite [...] por via da educação, da ocupação e da carreira política" (Idem, ibid.). Muitos desses membros da elite tinham formação jurídica em Coimbra, eram avessos a "doutrinas revolucionárias" (Idem, p. 39), costumavam passar pela magistratura e circulavam por "vários cargos políticos e por várias províncias" (Idem, ibid.). Em síntese, tinha-se uma "elite cosmopolita voltada para o modelo de civilização europeu", a dirigir uma "sociedade agrária e analfabeta" (Idem, p. 417).

$\mathrm{Na}$ virada do século XIX para o $\mathrm{XX}$, esse grupo social continua a mirar no "modelo de civilização europeu", mas passa a usar com mais frequência o exemplo americano. A faculdade de Direito continua a ser a preferida desses homens, mas já não saem tanto para Coimbra, tendo em vista que podem ter sua formação no Brasil, na cidade do Rio de Janeiro, São Paulo ou no Recife, por exemplo, para onde ia parte razoável dos membros da elite norte-rio-grandense (SANTOS, 2018). Com a República, as elites locais passaram a ter maior força, tendo em vista que a adoção do federalismo, mesmo com suas limitações, permitiu a esses grupos o domínio dos 
governos estaduais. Eram, porém, em essência os mesmos nomes que se via no período imperial (BUENO, 2002), com formação muito parecida e ainda tomando como referência o modelo europeu e, por vezes, o americano.

A descrição a seguir traz mais algumas características dessa elite no Rio Grande do Norte. Compunham tal grupo

\begin{abstract}
literatos ou técnicos, com formação em agronomia, engenharia ou medicina. Mas em geral eram bacharéis, na maior parte das vezes formados na Faculdade de Direito do Recife. Podemos delinear [...] o perfil do indivíduo integrante dessas elites: a política para ele é uma grande tentação, há uma forte probabilidade de em algum momento desempenhar um cargo na administração pública, (...) escreve nos jornais, publica em livro ou nos poucos jornais da terra [e] participa de iniciativas de natureza progressista que se organizam na cidade. [...] (ARRAIS; ANDRADE; MARINHO, 2008, p. 74).
\end{abstract}

Sebastião Fernandes, primeiro diretor da Escola de Aprendizes de Natal-RN, encaixa-se bem na descrição acima. Dedicou-se ao estudo das Humanidades, no Atheneu Norte-Riograndense, escola onde se formaram os homens que governaram os destinos do Rio Grande do Norte durante as primeiras décadas da República brasileira. Ainda jovem, antes dos vinte anos, partiria para o Recife, capital de Pernambuco, onde estudaria, também como tantos outros, Ciências jurídicas e sociais. Por essa época, já se dedicava também a rabiscar alguns versos, arte que continuou a cultivar enquanto esteve à frente da Escola de Natal. Seus pendores literários foram apresentados em entidades culturais como o grêmio literário Le monde, o Centro literário Castro Alves e o Congresso Literário, em Natal. Notas do jornal $A$ Republica, o de maior circulação no estado, indicam ainda que Fernandes se relacionava muito bem com outros membros da elite dirigente e que transitou por diferentes cargos da administração pública.

Em fins do século XIX, como dizíamos, esses homens tinham algo a resolver: tratar de controlar o espaço do negro na sociedade pós-escravidão e, em âmbito maior, das classes populares. A lei imperial no 601, lançada em 18 de setembro de 1850, já resolvia uma parte do problema, na medida em que ajudava a constituir a "moderna propriedade territorial” (SILVA, 2008, p. 18), tendo interditado a aquisição de terras devolutas por qualquer outro meio que não fosse a compra ${ }^{4}$. Na prática, a

\footnotetext{
4 Também inserida no contexto de abolição do sistema escravocrata no Brasil está a lei eleitoral de 1881 (Decreto nํㅜ 3.029, de 9 de janeiro de 1881), pela qual ficaram proibidos de votar aqueles que não soubessem ler e escrever, o que impedia a participação de quase todos os libertos e, em geral, dos membros das classes populares, da política eleitoral. Ver J. M de Carvalho (2007, p. 24).
} 
lei dificultava bastante, para não dizer que impossibilitava o acesso à terra aos negros beneficiados pela abertura do processo de abolição da escravatura naqueles meados do século XIX, bem como a todos aqueles que não fossem homens de posses e rendas.

Com o 13 de Maio, esses despossuídos passaram a ser donos de sua força de trabalho. E era justamente nesse ponto, na visão do referido grupo social, que residia o problema capaz de obstar o desenvolvimento e pôr em xeque a ordem nacional. A Lei Áurea não resolvia, nem de longe, "o problema social da escravidão, o problema da incorporação dos ex-escravos à vida nacional" (CARVALHO, 2007, p. 23-24), à nova sociedade pós-abolição. Em especial, os membros da elite imperial se viam incumbidos da difícil missão de tornar esse liberto um trabalhador, para o que "medidas que obrigassem o indivíduo ao trabalho" eram indispensáveis, mas não de todo suficientes. Isso porque esses homens perceberam que essas medidas só seriam verdadeiramente frutíferas se fossem acompanhadas por um significativo "esforço de revisão de conceitos, de construção de valores" capazes de constituir uma "nova ética do trabalho" (CHALHOUB, 2001, p. 65).

Nessa perspectiva, um mês após a abolição da escravatura, o ministro da Justiça, Ferreira Vianna, apresentava aos parlamentares do Império um projeto que combatia a "mãe de todos os vícios" (ANAIS do Senado do Império do Brasil, 3, 1888, p. 309): a ociosidade. O Código Criminal do Império do Brasil, de 1830, já tinha um capítulo específico, o de número IV, dedicado aos "vadios e mendigos" (1830, p. 3233). Contudo, para Vianna, as penalidades impostas a esses sujeitos não vinham se mostrando eficazes, o que tornava necessário o estabelecimento de uma nova lei, destinada a tratar dos casos de vadiagem e mendicância.

A questão era vista com urgência. A partir da Lei Áurea, milhares de homens que antes viviam no regime da escravidão tornaram-se libertos, sem terem, na visão dos que dirigiam o Império, condições de viver harmonicamente em sociedade. Isso porque, de acordo com essa visão, "a escravidão não havia dado a esses homens nenhuma noção de justiça, de respeito à propriedade, de liberdade" (CHALHOUB, 2001, p. 68), o que poderia facilmente levá-los, no discurso da elite republicana, ao mundo da vadiagem, dos vícios e dos crimes.

O Código Criminal de 1830 não se mostrava eficiente, pois não bastava apenas reprimir. Era preciso educar para o labor; mostrar aos libertos que o trabalho era o 
"valor supremo da vida em sociedade" (Idem, p. 69). Era nessa linha que seguiam as palavras de Ferreira Vianna. O ministro ressaltava que os pensadores modernos já não mais viam a pena como simples castigo, mas sim como elemento capaz de educar, de formar um novo sujeito, um "cidadão útil” (ANAIS do Senado do Império do Brasil, 6, 1888, p. 152). Esse "cidadão útil" seria forjado por meio de um árduo esforço de educar o povo, e os exemplos a serem seguidos, de acordo com a fala do deputado Manoel Peixoto, eram claros: os Estados Unidos e a Inglaterra.

Peixoto, porém, se colocava contra a proposta de Vianna, pois avaliava que o Brasil estava ainda muito distante dos melhores exemplos a serem seguidos e entendia que os frutos da educação popular demorariam a ser colhidos. Até lá, o governo precisaria adotar medidas mais fortes do que as presentes no projeto do ministro para combater a ociosidade. Pela proposta de Vianna, deveriam ser criados estabelecimentos de correção para aqueles que infringissem o "termo de bem viver", ou seja, que vivessem na ociosidade, vadiagem e mendicância (ANAIS do Senado do Império do Brasil, 3, 1888, p. 310).

A correção viria pelo trabalho. Os apenados seriam levados a estabelecimentos de correção em ilhas marítimas ou noutros pontos indicados pelo governo, onde realizariam trabalhos no campo ou em oficinas. Os infratores deveriam compreender o valor do trabalho como elemento fundamental para a vida em sociedade. Por isso, parte do produto dos apenados seria destinada a eles mesmos após saírem do estabelecimento de correção, pelo que poderiam perceber o significado de ganharem a vida com o suor do próprio rosto, de maneira digna e honesta.

Essa tomada de consciência, na visão de Vianna e dos que apoiavam seu projeto, não era algo simples de acontecer entre o povo brasileiro, pois nas terras de cá, diziam como que parafraseando Pero Vaz de Caminha, o que se via era a riqueza do solo e a abundância por toda a parte. Nas palavras do deputado Rodrigues Peixoto, "o indivíduo entre nós, para subsistir, tem facilidade de obter a carne, o peixe, o fruto [...]; não experimenta grandes necessidades, nem tem [...] o mesmo incentivo dos países pobres" (ANAIS do Senado do Império do Brasil, 6, 1888, p. 152). Nesses países, completava o deputado, o trabalho era uma grave necessidade; aqui, porém, a facilidade da vida levava à proliferação de ociosos, vadios e viciados.

Reprimir a ociosidade manifestada em boa parte da população era tarefa daqueles que vigiavam a ordem nacional e queriam ver o Brasil confirmar para o 
mundo o seu estatuto de país civilizado. Na visão da elite imperial, essa era uma tarefa hercúlea. Com constância, os parlamentares se referiam às "classes perigosas" que compunham o povo brasileiro. O termo foi retirado da literatura europeia da época, em especial dos autores franceses. Mas no Brasil a expressão teve seu sentido bastante alargado: "classes perigosas" passou a ser sinônimo de "classes pobres" para os legisladores do Império. Sem receio, podemos dizer também que, na República, terá sido sinônimo de "desfavorecidos de fortuna" (CHALHOUB, 2001, p. 76).

No discurso dos que dirigiam o Império, os pobres apresentavam "maior tendência à ociosidade", eram "cheios de vícios, menos moralizados" (Idem, p. 48) e podiam, muito facilmente, se entregar ao mundo do crime. Isso significava que recorrer aos imigrantes europeus para substituir os escravos libertos poderia atenuar o problema, na medida em que os homens vindos do Velho Continente, além de serem racialmente mais puros, na visão dos que dirigiam o Império, tinham bem incorporada a cultura e a ética do trabalho, servindo como bons exemplos aos trabalhadores nacionais. Mas esse processo de substituição de mão de obra não resolveria a questão, ao menos em curto e médio prazo, já que não seria suficiente para transformar os tão numerosos integrantes das ditas "classes perigosas" em legítimos trabalhadores, em cidadãos úteis à nação. O uso de medidas coercitivas, em um horizonte mais curto, e a educação das classes populares, a médio e longo prazo, eram os caminhos a serem trilhados.

É válido reforçar que essa tal ociosidade das ditas classes perigosas e sua tendência à vadiagem, são elementos que fazem parte de uma construção da elite que dirigia o Brasil no Império e que permanecerá firme na condução da República, ao menos até 1930. A hipótese defendida por Chalhoub é de que o discurso desse grupo social "justifica os mecanismos de controle e sujeição dos grupos sociais mais pobres" (Idem, p. 80). Os mitos da preguiça, da promiscuidade e da tendência natural ao crime e vícios daqueles que conhecemos mais por desfavorecidos de fortuna foram usados pelos que comandaram os destinos da nação como elementos de justificativa para o controle desses sujeitos. A escola vai ser uma das instituições usadas por essa elite para estabelecer esse controle.

Inventada na segunda metade do século XIX, a instituição escolar tem a capacidade de "estabelecer padrões comuns de comportamentos e valores" (HOBSBAWN, 2002, p. 301). Esses padrões, devemos dizer, são definidos por um 
centro de poder no qual se encontram a elite ou os grupos dirigentes. A Escola, mais do que estabelecer, difunde-os, (im) pondo-os como regras a serem seguidas, quase dogmas, sem questionamentos. Não queremos negar a existência desses questionamentos, das resistências às autoridades escolares: entre a letra fria da norma e sua recepção pelos grupos aos quais ela é destinada, há uma distância que não pode ser desconsiderada. Mas tais autoridades valem-se dos diversos mecanismos disciplinares, alguns dos quais previstos nas leis e regulamentos relativos às instituições escolares, para controlar e punir aqueles que procuram resistir. É possível que essa seja uma das razões para os índices elevados de evasão vistos na Escola de Aprendizes de Natal.

A Escola enquanto instituição pode ser concebida também como espaço dedicado a combater o "pecado da ociosidade" - tão temido pelos dirigentes republicanos no Brasil - e impedir que a mocidade tenha uma "vida lastimosa" (AFONSO, 2014, p. 93-94). A referência vem de um estudo sobre um projeto pedagógico alternativo de educação em Portugal, na transição do XIX para o XX, liderado por correntes do Protestantismo. Em nosso caso, analisamos um projeto centralizado pelo governo federal brasileiro e que se quer hegemônico. Mas ambos os casos se inserem, seja em Portugal ou no Brasil, em momentos de transição: do século XIX para o XX, da Monarquia para a República; e nesse contexto de transformações a Escola aparece como o espaço de "regeneração", capaz de contribuir significativamente para o ordenamento social.

O projeto de Ferreira Vianna foi elogiado por alguns parlamentares do Império brasileiro justamente pela preocupação em educar por meio do trabalho. Os estabelecimentos de correção defendidos por Vianna deveriam, seguindo os preceitos dos pensadores modernos, ensinar e não apenas punir. As ações não eram antagônicas, mas o punir só faria sentido se tivesse como fim o ensinar. E as escolas, nesse contexto, não seriam elas também estabelecimentos de correção? Elas apareciam, no contexto estudado, como o primeiro espaço capaz de corrigir aqueles que tendiam aos vícios e aos crimes, de retificá-los. Os presídios eram, talvez, o último caminho para esses homens. Educar a juventude apresentava-se como meio viável para evitar que aqueles que compunham as "classes perigosas" tivessem tal fim. $O$ pensamento de que abrir uma escola era fechar uma prisão, atribuído a Victor Hugo (CHESNAIS, 1999, p. 5), se difundia nas últimas décadas do século XIX, 
especialmente porque nos jovens em idade escolar se poderia inculcar mais facilmente as normas sociais valorosas para a manutenção da ordem.

Não sabemos exatamente que fim tomou o projeto de Vianna. O Império vivia seus últimos momentos. Pouco mais de um ano depois, a República era instaurada sob a simbólica liderança do marechal Deodoro da Fonseca, um antigo aliado da Monarquia. Relativamente à estrutura social, nenhuma mudança significativa se processou nesses tempos. Os dirigentes da recém-instaurada República temiam, como aqueles do "arcaico" Império, as tais classes perigosas. De maneira assertiva, podemos dizer que o "universo ideológico das classes dominantes brasileiras" não é alterado com a instauração da República, em 1889 (CHALHOUB, 2001, p. 78).

O regime republicano nascia desligado, apartado por completo das classes populares. Estava longe de representar o "ideal da coisa pública", a "tradição republicana popular" voltada para a "participação do povo na vida administrativa", como dizia o historiador Câmara Cascudo, ao tentar definir o conceito de República em sua História do Rio Grande do Norte (1984, p. 203). Esse povo, na verdade, continuava a causar medo e repulsa na elite dirigente. A expressão classes populares permanecia como sinônimo de classes perigosas.

O Brasil pode ser entendido como um "país exportador de matérias-primas e importador de ideias e instituições" (CARVALHO, 2005, p.84). Dos modelos importados pelos republicanos brasileiros, prevaleceu o positivista de viés ortodoxo, responsável por definir os símbolos e, por conseguinte, a identidade que deveria marcar o novo regime. O lema escolhido para compor a bandeira nacional, Ordem e Progresso, deixava claro o modo de pensar e agir daqueles que passaram a governar o Brasil a partir de 1889. Esses homens desejavam superar o que chamavam de "arcaísmo" do Império, elevar o Brasil ao nível das nações mais civilizadas e progressistas do mundo. Mas, para tanto, era necessário manter a ordem social intacta. O povo deveria assistir à República. Os dirigentes do novo regime tutelariam a massa popular, tida como incapaz de agir por conta própria (CARVALHO, 2014).

\section{Projetos de educação para os desafortunados do Império à República}

O Decreto n 7.566/1909 marcou o início da criação das Escolas de Aprendizes Artífices, espalhadas pelas capitais brasileiras. Uma obra ligada à República. Sem 
dúvida, o novo regime, estabelecido em 1889, inaugurou no Brasil uma nova era nesse campo de ensino, mas não devemos deixar de lado algumas iniciativas tomadas nessa área durante o período imperial.

Foram várias as instituições de Ensino Profissional criadas no governo do imperador D. Pedro II. Eis aí, de início, uma diferença marcante entre o Império e a República: na era imperial as iniciativas eram difusas; não havia uma ação centralizada por parte do governo que pudesse ser sentida em todo o território nacional. As ações partiam de sociedades formadas por particulares; por vezes, nasciam no interior dos governos provinciais, ou, em outros casos, do entrecruzamento de associações civis com o Estado (CUNHA, 2000, p. 109).

Entre as instituições de Ensino Profissional criadas no Império, estavam as casas de educandos artífices ${ }^{5}$. Ao todo, foram criadas dez entre 1840 e 1865, sempre pela iniciativa de presidentes de província, e todas localizadas na região Norte do país, com exceção da Casa de São Paulo. A do Rio Grande do Norte foi criada no ano de 1858, na gestão do presidente Antonio Marcelino Nunes Gonçalves.

O Colégio, aprovado pela Lei Provincial n 376, começou a funcionar com vinte alunos desafortunados, com idade entre 10 e 15 anos, e contava com as oficinas de alfaiate, sapateiro, carpina e pedreiro, ofícios voltados para as classes populares, de natureza artesanal ou que exigiam trabalho braçal. Além disso, os educandos artífices tinham aulas de primeiras letras - posto que a maioria deles eram analfabetos - a, princípios religiosos, geometria, mecânica, mecânica aplicada às artes e música.

A instituição começou a funcionar de maneira improvisada em prédio alugado no centro da cidade de Natal, capital do Rio Grande do Norte. Rita Gurgel, ao escrever sobre o Colégio, afirmou que "as condições físicas do estabelecimento não eram próprias para um abrigo, pois, além de poucos cômodos que oferecia, tinha uma altura de 12 palmos do pavimento ao forro de todas as salas", o que tornava esses espaços quentes, de modo a possibilitar com maior frequência o "surgimento de doenças de pele e também nos olhos dos alunos" (2007, p. 40). O plano era de que, com mais recursos, fosse construído um prédio próprio, adequado às demandas do estabelecimento. Mas ali, no prédio alugado na Rua Nova (hoje denominada Rio

\footnotetext{
5 Usamos "casa de educandos artífices" por ser esse o termo mais comum encontrado na literatura sobre o tema. Mas as denominações variavam de lugar para lugar, como afirma Cunha (2000, p. 113). No caso do Rio Grande do Norte, usava-se a denominação "Colégio de Educandos Artífices".
} 
Branco, localizada no centro da cidade), permaneceria até o seu fechamento, o que não tardaria a acontecer.

O próprio presidente da província afirmava que eram precárias as condições do estabelecimento. Boa parte das oficinas planejadas não estava em funcionamento, pois o número de alunos que o governo podia sustentar no Colégio era pequeno. As oficinas que funcionavam começam já a produzir, mas produção ainda acanhada, destinada para uso próprio dos educandos. Apesar dos pesares, o presidente Nunes Gonçalves, além de elogiar a disciplina do estabelecimento, ressaltava sua importância para pôr a província nas "vias do progresso" (1860, p. 10).

O futuro da instituição de ensino foi diferente, porém, do que imaginava Gonçalves. Em 1862, o presidente da província, Pedro Leão Veloso, tratava do encerramento das atividades da instituição por ter se tornado um "foco de imoralidades" (1862, p. 25). As razões devem ter sido outras (CASCUDO, 1980, p. 180) e, certamente, envolviam a falta de recursos nos combalidos cofres da província. Mas as palavras do presidente deixavam claros dois pontos significativos para nossa análise: a educação voltada para os desafortunados visava, antes de tudo, a reforma moral desses homens, e era pensada como obra de caridade (VELOSO,1862, p. 25). Ficou evidenciado, ainda, que o mito da promiscuidade das classes populares está presente no discurso do presidente da província, que põe a culpa do fracasso do Colégio na própria natureza dos alunos, imorais e cheios de vícios (Idem, ibid.). Ao fim do processo, a instituição não conseguiu formar um único educando.

Não sabemos bem as razões que levaram as demais Casas ao fim. Certamente, as dificuldades econômicas das províncias e a falta de apoio do Império ajudaram tais Casas a não durarem muito. De um modo geral, elas dependiam das iniciativas dos governos provinciais e não faziam parte de um projeto nacional, muito embora circulasse nos diferentes cantos do Brasil o discurso que pregava a necessidade de um cuidado especial com as ditas classes perigosas.

Acontecia que o governo imperial parecia ter demandas mais urgentes a resolver do que a da educação dos desafortunados. Era preciso lidar com o processo de abolição, com a oposição dos grandes proprietários de escravos, com a questão de terras e o equilíbrio político entre liberais e conservadores, entre outros pontos. Além disso, a educação como caminho para lidar com as "classes perigosas" apareceu mesmo como uma possível solução de ordem mais para o fim do século XIX, momento 
em que começou a se construir uma tradição escolar no Ocidente, sendo a escola vista como o espaço de conformação social e de transmissão, para os jovens escolares, dos valores e comportamentos que normatizam uma dada sociedade.

Nessa perspectiva, e também levando em conta as demandas por formação profissional técnica, foram criados diversos Liceus pelo Brasil ${ }^{6}$, entre os anos de 1858 e 1886. Eram eles mantidos por associações privadas que contavam com membros da burocracia estatal, o que, sem dúvida, ajudou tais instituições a angariar verbas governamentais para seu sustento material. Apesar disso, não se pode dizer que houve apoio firme e uniforme do governo imperial aos Liceus. $O$ do Rio de Janeiro, por exemplo, interrompeu suas aulas entre 1864 e 1867, por não terem chegado as verbas prometidas pelo governo. O Liceu da capital imperial dependia do trabalho de seus professores, que lecionavam, todos, gratuitamente (CUNHA, 2000, p. 123).

O Liceu de São Paulo, inaugurado em 1882, foi fundado, de acordo com o discurso dos membros da Sociedade Propagadora de Instrução Popular, para suprir uma "carência do Estado" (GORDINHO, 2000, p. 21). Sua função, ainda segundo seus fundadores, era formar o bom, consciente e útil cidadão (Idem, ibid.). Para isso, os alunos, em sua maioria de origem humilde, eram inseridos em um "culto ao trabalho" (Idem, p. 24), tendo em vista a correção de uma natureza que tenderia justamente ao contrário.

Os liceus do Rio de Janeiro e de São Paulo permaneceram vivos com a instauração da República. Na verdade, de acordo com Cunha, o Liceu de São Paulo passou a viver tempos de mais prosperidade, posto que boa parte dos sócios que o mantinham eram adeptos do movimento republicano. Mas o Estado republicano não chegou a assumir essas instituições, embora as subvencionasse. Elas seguiram caminhos distintos, mesmo que tivessem finalidades próximas. Não havia articulação entre elas para a definição de processos de seleção, cursos ofertados ou currículo praticado. O Ensino Profissional no Brasil ainda estava distante de alcançar alguma uniformidade nesses termos.

De resto, ainda no período imperial, surgiram diversos estabelecimentos militares voltados para a educação dos desfavorecidos de fortuna. As experiências desenvolvidas nesses espaços foram, inclusive, anteriores à criação de Liceus e

\footnotetext{
${ }^{6}$ Cunha (2000, p. 122) cita os Liceus do Rio de Janeiro (1858), Salvador (1872), Recife (1880), São Paulo (1882), Maceió (1884) e Ouro Preto (1886).
} 
casas de educandos artífices. Tais estabelecimentos - entre os quais, os Arsenais de Guerra da Marinha e Exército e as Companhias de Aprendizes Marinheiros - foram "os primeiros a explicitarem a utilização no Brasil, a partir da segunda metade do século XIX, de menores órfãos, pobres ou desvalidos, como matéria-prima humana para a formação sistemática da força de trabalho [...]" (CUNHA, 2000, p. 112).

Esses estabelecimentos uniam a rigidez das atividades e exercícios militares ao aprendizado de um ofício, sem abrir mão, ao menos em alguns desses espaços (Idem, p. 110), das práticas religiosas, ingredientes que eram fundamentais para o disciplinamento dos jovens desafortunados. Em Natal, cidade ainda muito acanhada no século XIX, não se chegou a fundar nenhum estabelecimento dessa espécie. Contudo, sabemos por meio de uma nota intitulada "Correio", do jornal A Republica, que um jovem órfão e desvalido, de nome João Gonçalves Germano, após ter sido preso pela prática de roubo no mercado público da cidade, foi entregue ao capitão do Porto de Natal, que deveria fazê-lo seguir para a Escola de Aprendizes Marinheiros do Rio de Janeiro ("Correio", 02 fev. 1899).

Se o jovem desafortunado João foi mesmo para o Rio, não sabemos dizer. Não vimos mais nenhuma referência a ele nos jornais locais. Na verdade, raramente esses desafortunados apareciam nesses periódicos, senão em relatos de crimes e vadiagem. Mas a matéria do jornal mostra, com clareza, que essas instituições comandadas pelos militares se destinavam, de fato, àqueles jovens que pertenciam às classes populares e que precisavam ser reformados moralmente, na visão da elite dirigente. A matéria revela, ainda, um tom de caridade na ação das autoridades locais.

Em 1889, viria a República. Mantinha-se a preocupação com as classes perigosas, o que pode ser evidenciado pelo Código Penal de 1890. A Constituição, promulgada em 1891, era vaga ao se referir ao papel do Estado republicano na educação. Afirmava a laicidade do ensino praticado nos estabelecimentos públicos e definia atribuições das unidades federativas (CONSTITUIÇÃO da República dos Estados Unidos do Brasil, 1891). Não citava o ensino técnico-profissional. Não significava isso que não houvesse, por parte dos líderes republicanos, preocupações com a educação das classes perigosas. Mas, também naquele momento, as prioridades eram outras. A Constituição deveria dar ordem, esboçar o novo Estado 
republicano e cuidar para que justamente essas classes não tivessem acesso ao poder, o que se fez com as graves restrições ao voto ${ }^{7}$.

O ano-chave para o Ensino Profissional no Brasil foi mesmo o de 1906. Neste ano, a Câmara dos Deputados propôs a inclusão de um crédito de até 100:000\$000 (cem contos de réis) no orçamento do Ministério da Justiça e Negócios Interiores, destinado à instituição de escolas técnicas e profissionais nos estados brasileiros.

Apesar de ser notada uma maior preocupação do governo federal e do Congresso com o campo da educação, deve-se observar que este não representava uma pasta específica, estando integrado ao referido Ministério. Isso revela, como apontamos anteriormente, que a educação - incluso, é claro, o ramo profissional era vista essencialmente como meio para manter a ordem social. Apenas em 1930, com a chegada de Vargas ao poder, foi criado o Ministério da Educação e Saúde Pública. Em 1937, passou a se chamar Ministério da Educação e Saúde. Antes disso, houve o Ministério da Instrução Pública, Correios e Telégrafos, criado no governo provisório da República (1890) e inicialmente dirigido por Benjamin Constant, mas já em 1891 essa pasta deixava de existir.

Observe-se, ainda, que a proposta da Câmara era lacônica quanto à implantação dessas escolas. Além de definir valores a serem gastos, ela apenas dizia que o Presidente da República deveria se entender com os governos dos estados para tal realização. Diante disso, podemos dizer que não estava de fato claro como se desenvolveria o ensino profissional no Brasil naquele início de século $\mathrm{XX}$.

Por outro lado, vemos pela discussão nos Anais do Senado que os dirigentes republicanos começavam a apresentar maior preocupação com o desenvolvimento desse ramo de ensino, o que pode ser percebido pela emenda proposta pela Comissão de Finanças daquela casa legislativa, pela qual a verba destinada para a implantação das ditas escolas técnicas e profissionais passaria de cem contos de réis para quinhentos (ANAIS do Senado Federal, 1906, p. 901). Nem todos, porém, mostravam-se satisfeitos com a proposição de mudança feita pela Comissão.

O senador Barata Ribeiro, do estado do Rio de Janeiro, apresentava-se como defensor da instrução pública e afirmava a necessidade de dar-lhe um cunho prático.

\footnotetext{
7 O Art. 70, $\S 1^{\circ}$, da Constituição Federal de 1891, interditava o voto aos analfabetos, mendigos, praças de pré e religiosos sujeitos a voto de obediência. Segundo Sobreira (2008), "apesar do fim do critério pecuniário dois anos antes, o número de eleitores não cresceu, pois a exigência da alfabetização, tanto para votar como para ser votado, excluiu a maioria da população".
} 
Contudo, alegava que não estava claro na proposta o que se queria dizer com escolas técnicas e profissionais. A dúvida era pertinente. O senador destacava que essa falta de clareza poderia levar ao aumento da "possibilidade de erros" e "sacrificar o interesse público" (Idem, ibid.) e temia, ainda, que o governo usasse a amplitude da expressão "escolas técnicas e profissionais" para criar profissões, de maneira arbitrária, sem considerar as demandas da economia nacional.

Não seria ainda naquele momento que o governo republicano despenderia seus esforços no desenvolvimento do Ensino Profissional no Brasil. Mas, de qualquer modo, vemos que naquele ano de 1906 começava a tomar corpo e a se fixar a ideia da necessidade do governo federal intervir na questão, razão pela qual pode-se dizer que a proposta da Câmara dos Deputados pode ser tomada como um marco significativo para a história do ensino industrial no Brasil.

Ainda no referido ano, o então candidato à presidência, Afonso Pena, tratava, em seu manifesto, da criação de escolas de ensino técnico e profissional como meio para desenvolver a indústria nacional (Idem, p. 172). Pouco tempo depois, Pena tornou-se o primeiro presidente a se referir a esse ramo de ensino no seu discurso de posse de 1906, enfatizando que "a criação e multiplicação de institutos de ensino técnico e profissional muito podem contribuir também para o progresso das indústrias, proporcionando-Ihes mestres e operários instruídos e hábeis" (PENA Apud BONFIM, 2004, p. 97) e auxiliando as escolas de comércio já existentes.

É também de 1906 o Decreto no 1.606, pelo qual é criado o Ministério da Agricultura, Indústria e Comércio. Caberia a essa nova pasta, entre outras atribuições, o desenvolvimento do ensino agrícola e profissional, compreendendo este os estabelecimentos voltados para a indústria. Mas o ano de 1906 estava já em seus últimos dias e nada mais se fez naquele momento.

No ano seguinte, concluído o primeiro ano de seu mandato, o presidente Afonso Pena falava ao Congresso sobre suas ações no governo e os problemas a serem enfrentados pela nação brasileira. Dentre esses, destacava a Instrução Pública, que vivia, segundo o presidente, "num regime de vacilações e incertezas", de modo a necessitar de "uma reforma séria e capaz de satisfazer as exigências do ensino moderno", a qual deveria ser guiada pelos exemplos praticados em países da Europa ocidental e nos Estados Unidos. Por fim, Pena dava ênfase ao Ensino Profissional e 
Técnico, destacando, como fizera em seu discurso de posse, sua importância para o "progresso da lavoura, do comércio, indústria e artes" (PENA, 1907, p. 17).

Em 1908, Afonso Pena nem chegou a proferir palavras novas sobre a Instrução Pública. Apenas pedia, mais uma vez, atenção do Congresso para o problema enfrentado pelo Brasil nessa área. No ano de 1909, nenhuma surpresa. Ao citar reformas das quais o Brasil precisava para seu desenvolvimento, destacou 0 "problema do ensino", que reclamava uma "solução inadiável" (PENA, 1909, p. 17). É, sem dúvida, um discurso repetitivo. Mas revelava um novo olhar do Estado republicano sobre a Instrução Pública, com uma ênfase que não se via antes no Ensino Profissional e Técnico.

\section{As Escolas de Aprendizes Artífices: um novo olhar da República sobre a Educação Profissional}

No governo de Afonso Pena, contudo, não houve mais tempo para reformas. presidente viria a falecer em 14 de junho de 1909, sem chegar a concluir seu mandato. Seu vice, Nilo Procópio Peçanha, assumiria naquela mesma data a presidência do Brasil. O novo presidente, na época em que foi governador do estado do Rio de Janeiro, já havia investido no Ensino Profissional, criando, por meio do Decreto ํo 787/1906, três escolas para ensino de ofícios e uma outra para o aprendizado agrícola, nas cidades de Campos, Petrópolis, Niterói e Paraíba do Sul (FONSECA, 1986, p. 174). Pouco mais de três meses após assumir a presidência da nação, seria a vez de, por meio do Decreto n 7.566/1909, criar uma rede de escolas que aliavam o Ensino Primário ao Profissional, espalhadas pelos estados brasileiros.

O referido decreto, lançado em 23 de setembro de 1909, deixava claro que essas Escolas eram destinadas, preferencialmente, aos desfavorecidos de fortuna, um eufemismo para classes perigosas. Os jovens aprendizes chegavam à Escola com 10 ou 12 anos, em média, e lá ficavam por quatro anos aprendendo, simultaneamente, as primeiras letras e um ofício. Quanto à profissão a seguir, havia, normalmente, cinco opções. Os aprendizes de Natal, após dois anos de formação geral, podiam seguir nos cursos de Alfaiataria, Funilaria, Marcenaria, Sapataria ou Serralharia.

Permanecia naqueles que dirigiam a República brasileira o medo em relação às classes perigosas. Mantinha-se, igualmente, a concepção de que o ensino poderia 
transformar a alma daqueles desfavorecidos de fortuna, fazendo com que adquirissem "hábitos de trabalho profícuo" que os afastassem da "ociosidade, escola do vício e do crime" (DECRETO n 7.566, 1909, p. 1). A letra da lei deixava claro que ainda se temia o povo e que os mitos da preguiça, da promiscuidade e da tendência natural ao crime e aos vícios, continuavam a ser associados às classes populares.

Nesse sentido, não podemos atribuir um "espírito renovador" (FONSECA, 1986, p. 160) à República brasileira. O novo regime, com um velho olhar marcado por paradigmas ainda do período imperial, lançou novas estratégias para controlar as classes populares, entre as quais aquela que nos interessa, a criação de uma rede de Ensino Profissional, destinada a educar e transformar homens ociosos e vadios através da cultura do trabalho, conforme se via no seu decreto de criação.

Entre a Proclamação da República e a criação das Escolas de Aprendizes, passaram-se vinte anos. O desejo por educar as "classes perigosas" já era claro no final do século XIX, mas a República tinha outras batalhas a travar. Por exemplo, o regime precisava criar uma identidade, um herói - Tiradentes foi o escolhido (CARVALHO, 2007, p. 55-73) -, conter a oposição de resistentes monarquistas, derrotar os sertanejos de Canudos liderados por Antônio Conselheiro, e estabelecer uma política de controle sobre os estados da federação.

No início do século XX, essas batalhas já haviam sido vencidas pela República. Especialmente a partir do governo de Campos Sales (1898-1902), o governo federal conseguiu uma relação de equilíbrio com as oligarquias estaduais que, por sua vez, em troca de verbas aos seus estados e cargos federais aos seus apadrinhados, garantiam a sustentação do poder do regime republicano. O povo, é claro, não fora incluído nesses acordos. A República não era pensada para ele.

Nos anos seguintes ao governo Campos Sales, a Educação Profissional passou a ser tema mais comum nos relatórios dos presidentes e chegou, pela primeira vez, a um discurso de posse. Foi nesse momento, também, que começaram a se formar os primeiros grupos escolares em boa parte dos estados brasileiros, como foi o caso do Rio Grande do Norte, cujo governo inaugurou, no ano de 1908, o grupo escolar Augusto Severo ${ }^{8}$. No estado do Sergipe, também localizado no que é hoje a região

\footnotetext{
${ }^{8}$ Apenas no período de 1908 a 1914, no segundo governo de Alberto Maranhão, foram criados vinte e seis grupos escolares, dois em Natal (além do Augusto Severo, foi criado o Frei Miguelinho, em 1912), e os demais no interior do estado. Entre 1916 e 1927, foram criados mais treze grupos (AZEVEDO; STAMATTO, 2012, p. 43-44). Por essa ação e também pela criação do Teatro Carlos Gomes,
} 
Nordeste, esses grupos começaram a surgir a partir do ano de 1911 (AZEVEDO; STAMATTO, 2012, p. 27). Na cidade de Belo Horizonte, capital planejada do estado de Minas Gerais, os grupos escolares foram criados também a partir de 1908 (FARIA FILHO, 1998, p. 2), onze anos após a inauguração da cidade. Escola e espaço urbano estavam, em todos esses casos, imbricados.

Os grupos escolares eram formados pela reunião de escolas isoladas ou, dito de outro modo, uma "federação de escolas" (DECRETO n² 239, 1910, p. 122) que passou a adotar o sistema seriado de ensino. É ainda válido lembrar que os espaços escolares, neste momento, passaram a ser "alvo dos preceitos do higienismo e da arquitetura que indicavam, entre outros aspectos, a necessidade de que os prédios escolares tivessem salas amplas, arejadas, com iluminação natural” (CRUZ, 2014, p. 53), de modo a facilitar o desenvolvimento e a aprendizagem dos alunos. Esses mesmos preceitos influenciaram os regulamentos das Escolas de Aprendizes de 1911 e 1918. Tanto os grupos quanto as Escolas que estudamos estavam, ainda, vinculados ao discurso da elite que visava justificar um ordenamento social, especialmente a partir do início do século XX, com ênfase no enquadramento das classes populares, bem como o desenvolvimento econômico através da educação. Essas instituições pretendiam, em síntese, pôr em prática o discurso da Ordem e Progresso (AZEVEDO; STAMATTO, 2012).

É na cidade que o regime republicano tentará mostrar a sua face mais encantadora e moderna. Destacam-se, no início do século XX, as obras do prefeito Pereira Passos, que governou o Rio de Janeiro, capital federal entre os anos de 1902 e 1906. Antes do engenheiro Passos, no início do regime republicano, o Rio de Janeiro havia sido governado por um médico, Cândido Barata Ribeiro, que realizou uma operação de "limpeza" do centro do Rio, retirando dessa região da cidade os cortiços, entre os quais o famoso "cabeça de porco" 9 , habitados por membros daquelas "classes perigosas".

Temos, portanto, um processo de modernização excludente (FAORO, 2000). Deve-se destacar que esse processo é sentido também na Natal do início do século XX. No ano mesmo da publicação do Decreto nº 7.566, uma crônica lançada no jornal

inaugurado em 1904, no seu primeiro governo, e reformado entre 1908 e 1912, Alberto Maranhão ficou conhecido como Mecenas Potiguar.

9 Para uma análise desse processo de "limpeza" do centro do Rio de Janeiro na gestão de Barata Ribeiro, ver Richard Negreiros de Paula (2003). 
A Republica dava o tom das transformações materiais pelas quais a cidade vinha passando, narradas pela visão daqueles que comandavam o governo do Estado e de sua capital. No texto, o personagem Epaminondas pega o bonde elétrico, deparandose com uma touriste smart vinda do Rio de Janeiro. Encantado pela elegante senhora, resolve desvendar-Ihe a nova cidade que ia se descortinando no trajeto do bonde.

Epaminondas fazia questão de dizer à dama carioca que Natal muito progredira nos últimos anos, e que todo esse avanço vivido pela cidade só havia sido possível com a instauração da República. O novo regime criara uma "cidade quase nova" ("Notas", 02 jun. 1909), mesmo tendo que lidar com condições econômicas "sempre precárias" (Idem). Não cabe, aqui, analisar tais condições, mas é válido ressaltar que elas são constantemente alegadas nas matérias de $A$ Republica, como elemento que reforça o caráter regenerador do novo regime. Não é de se estranhar que o único momento de discordância entre a gentil lady e o cavalheiro natalense tenha se dado quando ela se referiu à "maldita política". Epaminondas não se conteve e, em tom ufanista, afirmou que à política "devemos tudo" (Idem).

São várias as passagens e os símbolos que denotam o progresso vivido pela cidade naqueles anos iniciais do século XX. $O$ bonde é um desses símbolos, que remete à ligação de diferentes espaços da cidade, espaços antes distantes, desconectados. Traz velocidade e ânimo novo à urbe. O porto da cidade, onde desembarcara a touriste smart, era outro desses elementos que representavam a modernização da cidade, porta de entrada da urbe natalense, vinha passando por reformas naqueles tempos, as quais visavam ampliar os contatos da progressista Natal com o restante do mundo civilizado. E, ainda, a referência ao bairro de Cidade Nova - correspondente hoje aos bairros de Tirol e Petropólis -, apresentado na crônica como a "nova cidade", trazendo-nos a impressão de que os homens que arquitetaram o primeiro bairro planejado de Natal criam que os seus ares poderiam ser irradiados para o restante da urbe. Todos esses elementos refletem, do ponto de vista dos que estavam à frente da gestão do Estado e sua capital - não nos esqueçamos que o jornal $A$ Republica representa essas vozes - o processo de modernização de Natal, e são facilmente percebidos na fonte analisada.

Há, porém, outro aspecto importante desse processo de modernização, que caminha ao lado das transformações materiais e não pode ser negligenciado: a educação. Epaminondas, além de exaltar as transformações materiais vividas pela 
cidade, destacou também mudanças importantes na área da educação, dentre as quais citou a reorganização do ensino primário no estado ${ }^{10}$, incluindo a criação de grupos escolares na capital e no interior e a inauguração da Escola Normal de Natal, em 1908. E por que esse aspecto não pode ser negligenciado?

Em resposta a essa questão, devemos lembrar que aqueles que dirigiam os destinos do Rio Grande do Norte e da capital potiguar referiam-se diversas vezes, em especial nas matérias do jornal $A$ Republica, a um descompasso entre as transformações materiais realizadas em Natal e o comportamento de seus habitantes, que pareciam desconhecer, na visão dos dirigentes, o valor daquelas mudanças vividas pela cidade. Era como se houvesse um descompasso entre o corpo e a alma da cidade. Nesse sentido, é válido apontar que, na República, o projeto de desenvolvimento da educação, em especial voltado para os desafortunados, e de modernização das cidades, caminharam lado a lado. Ambos remetiam à ideia do novo, ao desejo do país de integrar o concerto das nações civilizadas e progressistas e de, ao mesmo tempo, estabelecer uma identidade à República recém-instituída. Se a Monarquia era símbolo do velho, do arcaísmo, do atraso, a República, por sua vez, representava o novo, o moderno, o espírito do progresso.

Deve-se observar ainda que a cidade é o local por excelência daquelas classes perigosas. Nela se amontoam os homens marcados pelos vícios, os desocupados, vadios, aqueles, enfim, que importa controlar para a manutenção da ordem. Não é coincidência que nas cidades se concentrem os asilos, hospitais, leprosários, prisões e as escolas, instituições que se multiplicaram no Brasil entre fins do século XIX e início do XX. Instituições de vigilância, disciplinares (FOUCAULT, 2009), mas que, é certo, não são hermeticamente fechadas, nem impermeáveis a resistências.

Nesse contexto, a urbe podia ser representada como espaço de encanto ou medo, de desejo ou repulsa. Mas no início do século XX era vista, em essência, como espaço do moderno, com todas as contradições que the são peculiares. As Escolas de Aprendizes foram um símbolo do processo de "incorporação do operariado à modernidade urbana pela via do trabalho" e, ao mesmo tempo, "de criação de uma nova ordem, expressão da vontade republicana" (CHAMON; GOODWIN, 2012, p. 330) de estabelecer um novo significado ao trabalho, associando-o ao ser cidadão.

10 Para uma análise dessa reorganização, feita em especial por meio da Lei Estadual ㄲo 249/1907 e pelo Decreto Estadual no 178/1908, ver A. Morais; F. Silva (2009). 
As instituições às quais nos referimos há pouco - asilos, hospitais, leprosários, prisões e escolas - faziam parte de uma experiência do moderno. As Escolas de Aprendizes Artífices nasceram exatamente nesse contexto em que o desejo pelo moderno, pelo Progresso - palavra por vezes grafada com inicial maiúscula, como uma força maior a mover os homens - unia-se a uma necessidade expressa pela elite dirigente de controlar uma massa perigosa de pobres desordeiros, que, segundo alegação dessa elite, era incapaz de compreender os valores do moderno, da civilização. As Escolas deveriam cuidar desses homens, discipliná-los e, ao mesmo tempo, contribuir para o progresso material da nação, para o desenvolvimento da indústria brasileira.

Em que medida tais Escolas conseguiam fazê-lo? Eis uma questão para a qual devemos buscar resposta. A missão dessas Escolas não era, de fato, simples. O primeiro passo já havia sido dado: a educação e, mais especificamente, o Ensino Profissional eram pontos de pauta mais caros ao governo republicano no início do século XX. Mas entre elaborar um decreto estabelecendo a criação das Escolas de Aprendizes Artífices e fazê-las funcionar, havia um longo caminho a ser percorrido.

A experiência era nova no Brasil. Nos estados não havia muitos exemplos a serem seguidos. Uma exceção era o Instituto Parobé, fundado em Porto Alegre-RS, no ano de 1906, voltado desde o início de suas atividades para uma formação mais prática e especializada dos aprendizes. Esse Instituto se tornaria uma referência às demais Escolas de Aprendizes, especialmente a partir da década de 1920, quando se criou o Serviço de Remodelação do Ensino Profissional, chefiado pelo engenheiro João Luderitz, professor do referido Instituto.

O Serviço de Remodelação buscou dar uniformidade às Escolas de Aprendizes, em especial estabelecendo um modelo de ensino mais prático, baseado no taylorismo (GURGEL, 2007; QUELUZ, 2000), e uma base curricular válida para todas as Escolas. A partir daí, essas instituições começaram a seguir novos rumos.

\section{Considerações finais}

Voltando a 1909, vemos que o decreto oㅜ 7.566, responsável por criar as Escolas, era pouco esclarecedor quanto ao funcionamento dessas instituições. Não havia regulamento, nem prazos estipulados para conclusão dos cursos, e seus 
programas deveriam ser formulados por cada um dos diretores. O essencial parecia ser mesmo o caráter moralizante da instituição escolar, ficando para depois o aspecto de formação profissional. Isso pode ser observado não só na introdução do Decreto no 7.566 e no teor de outras leis, mas também nos relatórios do Ministério da Agricultura, Indústria e Comércio. Em 1910, o ministro Rodolpho Miranda ressaltava que as Escolas deveriam "impedir a tendência do menor à ociosidade, despertandoIhe o amor pelo trabalho", de modo a "convertê-lo em criatura útil à sociedade, pelo aprendizado profissional” (MIRANDA, 1910, p. 136; grifos nossos).

A presença da preposição "pelo" indica, claramente, que o aprendizado profissional representava um meio e não um fim em si mesmo. Tratava-se de Escolas mais da ordem do que do Progresso, mais voltadas para a conformação social do que para o desenvolvimento econômico. Em síntese, o intento maior dessas Escolas era formar o cidadão ordeiro, disciplinado; o meio para tal era impregnar no aprendiz a cultura do trabalho.

Interessante é também observar a presença do conceito de menor em diversos documentos que se referem aos aprendizes das Escolas. Tal conceito começa a ser disseminado no final do século XIX e representa aquelas crianças pobres das urbes, que vagavam por suas ruas, praças, muitas vezes imersas no mundo do crime, abandonadas "tanto material como moralmente" (LONDOÑO, 1991, p. 135), tendo em vista que seus pais ou tutores, entregues aos vícios e à vadiagem, não exerciam sobre elas nenhuma autoridade. Nesse sentido, cabia ao Estado guardá-las e cuidar para que fossem tornadas cidadãs úteis.

Esse conceito aparece no próprio decreto de criação das Escolas ${ }^{11}$ e se repete em outros relatórios ministeriais, o que deixa claro qual a visão que a República tinha sobre os alunos dessas Escolas: jovens que precisavam ser moralmente reformados. Sua transformação em cidadãos úteis não deveria significar, porém, uma mudança de posição social. O ministro Pedro de Toledo dizia, em 1911, que "aqueles que tiverem aproveitado o aprendizado dessas escolas, formarão uma classe de cidadãos que, sabendo dignificar a pobreza, irão prestar, certamente, serviços úteis à sua pátria" (TOLEDO, 1911, p. 311).

\footnotetext{
11 "Nas Escolas de Aprendizes Artífices, custeadas pela União, se procurará formar operários e contramestres, ministrando-se o ensino prático e os conhecimentos técnicos necessários aos menores que pretendem aprender um ofício" (Decreto $\mathrm{n}^{\circ} 7.566,1909$, p. 1; grifo nosso)
} 
Nem sempre, porém, essa disciplina era obedecida. No relatório ministerial de 1914, chama-nos a atenção o fechamento da Escola Agrícola da Bahia, sob a alegação da presença de "sintomas de franca indisciplina naquele estabelecimento de ensino", de modo a gerar a um clima de "desordem" (VIEIRA, 1914, p. XIV) na dita instituição. A culpa estava, segundo o relatório, no comportamento da clientela, também formada pelos desfavorecidos de fortuna, que agiam como "irresponsáveis" (Idem, ibid.), tendo entrado em atrito, inclusive, com o diretor da Escola.

É certo que a indisciplina alegada no relatório não foi a única razão que levou ao fechamento da Escola. O Decreto ㄲo 10.855/1914, que estabeleceu o fim das atividades na instituição, cita, entre outros pontos, falta de recursos orçamentários, sem se referir, em momento algum, a casos de indisciplina. Não se deve, de qualquer modo, desconsiderar o que está dito no relatório, tendo em vista que instituições como a Escola Agrícola da Bahia, voltadas para os desafortunados, costumavam apresentar normas disciplinares rígidas.

Era assim na Escola de Aprendizes Artífices de Natal e nas outras do gênero. Nenhuma delas chegou a fechar as portas. Contudo, da Escola de Natal, alguns alunos foram eliminados a bem da disciplina ou da moral, por exemplo, além de centenas de outros que, como nos mostram os livros de matrícula, abandonaram a Escola por razões diversas, entre as quais a mudança para cidades do interior, onde certamente viviam parte de suas famílias e onde, talvez, o sustento material pudesse ser conquistado com menos dificuldade do que na capital.

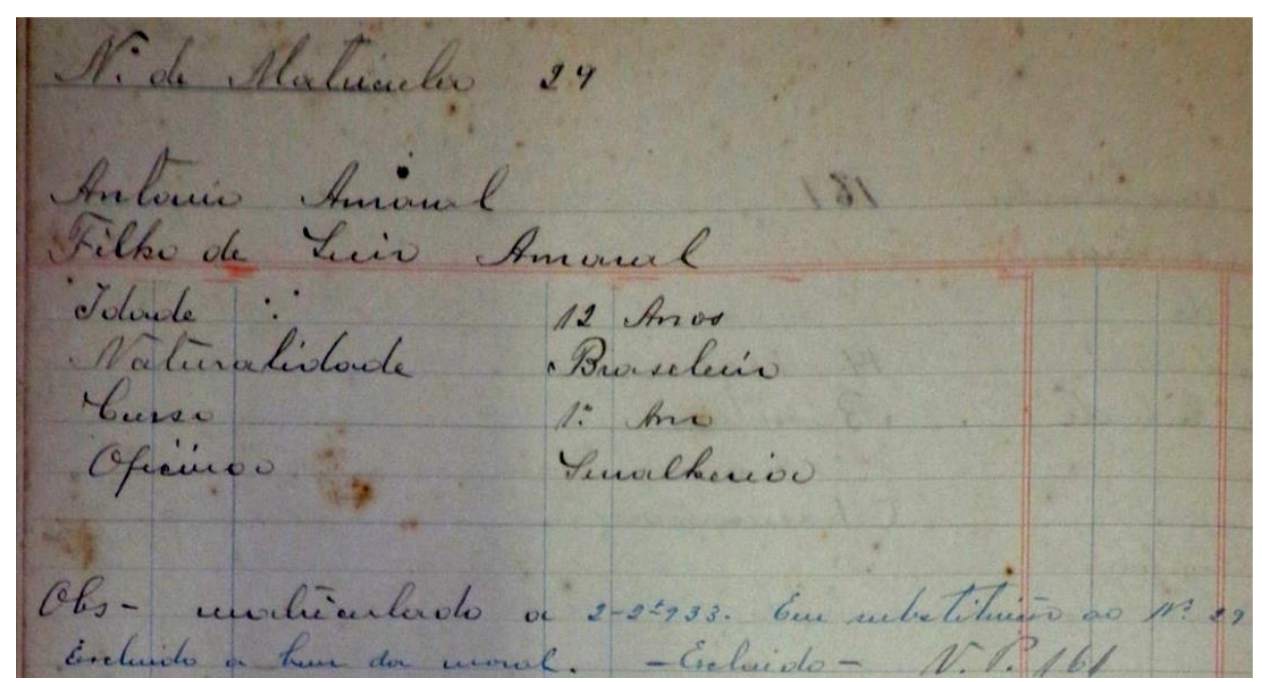

Imagem 01: registro do aluno Antonio Amaral, presente no livro de matrículas do ano de 1933 Fonte: acervo do IFRN, campus Natal-Central. 
A expressão "a bem da moral" (em destaque) não explicita que ato cometido pelo aprendiz, ainda em seu primeiro ano de Escola, teria levado à expulsão. Mas ela evidencia que essa instituição se apresentava como guardiã de uma determinada moral. Essa moral ligava-se aos valores do grupo responsável pela criação das Escolas de Aprendizes, a elite que comandou os destinos da República brasileira no período estudado. Referimo-nos, em especial, a uma cultura do trabalho que se contraporia à indolência e vadiagem associadas às classes pobres.

A eliminação do aprendiz Antonio Amaral e de centenas de outros na Escola de Natal reforçava o espírito republicano no Brasil. O projeto de uma rede profissional de ensino iniciado pelo decreto $\mathrm{n}^{0}$ 7.566/1909, voltado para a educação de "menores", visava torná-los dignos pela cultura do trabalho, deixando também claro para eles sua posição na sociedade. Deviam "dignificar a pobreza”, não a superar. Em síntese, para os dirigentes republicanos no início do século XX era preciso que tudo mudasse para que tudo permanecesse como estava.

\section{Referências}

AFONSO, J. A. M. M. As representações da infância e da juventude na imprensa infanto-juvenil protestante portuguesa na transição do século XIX - uma leitura do Amigo da Infância (1874-1940). In: MORAIS, J. J. da Silva et al (org.). Secularidades e confessionalidades na História da Educação. João Pessoa: Sal da terra, 2014.

ANAIS do Senado do Império do Brasil, v. 3, 1888. Disponível em: http://www.senado.leg.br/publicacoes/anais/pdf/Anais_Imperio/1888/1888\%20Livro\% 206.pdf. Acesso em: 03 fev. 2016.

ANAIS do Senado do Império do Brasil, v. 6, 1888. Disponível em: http://www.senado.leg.br/publicacoes/anais/pdf/Anais_Imperio/1888/1888\%20Livro\% 206.pdf. Acesso em: 27 jun. 2016.

ARRAIS, Raimundo; ANDRADE, Alenuska; MARINHO, Márcia. O corpo e a alma da cidade moderna - Natal, entre 1900 e 1930. Natal: EDUFRN, 2008.

AZEVEDO, Crislane Barbosa; STAMATTO, Maria Inês Sucupira. Escola da ordem e do progresso: grupos escolares em Sergipe e no Rio Grande do Norte. Brasília: Liber livro, 2012.

BUENO, Almir de Carvalho. Visões de República: idéias e práticas políticas no Rio Grande do Norte (1880-1895). Natal: EDUFRN, 2002. 
CARVALHO, J. M. de. A formação das almas: o imaginário da República no Brasil. São Paulo: Companhia das letras, 2007.

A construção da ordem/Teatro de sombras. Rio de Janeiro: Civilização brasileira, 2008

Os bestializados. São Paulo: Companhia das letras, 2014.

Pontos e bordados: escritos de história e política. Belo Horizonte: EDUFMG, 2005.

CASTRO, H. M. M. de. Escravidão e cidadania no Brasil monárquico. São Paulo: Zahar, 2000.

CHALHOUB, S. Trabalho, lar e botequim: o cotidiano dos trabalhadores no Rio de Janeiro belle époque. Campinas: Ed. Unicamp, 2001.

CHAMON, C. S.; GOODWIN JR., J. W. A incorporação do proletariado à sociedade moderna: a Escola de Aprendizes Artífices de Minas Gerais (1910-1941). In: Varia Historia, n. 47, p. 319-340. 2012.

CRUZ, P. L. C. A. da. A educação como instrumento na construção do imaginário republicano: grupo escolar Barão de Mipibu (1909-1920). (Dissertação de mestrado não publicada). Universidade Federal do Rio Grande do Norte, Brasil. 2014.

FAORO, R. Os donos do poder. São Paulo: Globo, 2000.

FARIA FILHO, L. M. de. O espaço escolar como objeto da história da educação: algumas reflexões. In: Revista da Faculdade Educação, n. 24, p. 141-159. 1998.

GURGEL, R. A trajetória da Escola de Aprendizes Artífices em Natal: República, trabalho e educação (1909-1942). Tese de doutoramento, Universidade Federal do Rio Grande do Norte, Natal, Brasil. 2007.

HOBSBAWN, E. J. E. A produção em massa de tradições. In: HOBSBAWN, E. J. E; RANGER, T. (Orgs.). A Invenção das tradições. 3. ed. Rio de Janeiro: Paz e Terra, 2002, p. 271-316.

LONDOÑO, F. T. A origem do conceito menor. In: PRIORI, M. Del. História da Criança no Brasil. São Paulo: Contexto, 1991, p. 98-111.

MIRANDA, R. N. da R. Relatório apresentado ao Presidente da República dos Estados Unidos do Brazil pelo Ministro de Estado dos Negocios da Agricultura, Industria e Commercio, no anno de 1910, 1910. Disponível em: http://brazil.crl.edu/bsd/bsd/u2000/. Acesso em: 31 out. 2015.

MORAIS, A.; SILVA, F. de L. História da profissão docente em Natal/RN (19081920). In: Revista Diálogo Educacional, v. 9, n. 27, p. 267-278, 2009. 
PAULA, R. N. Jornalistas e o espaço urbano da Capital Federal nos primeiros anos da República: o caso do Cabeça de Porco. In: Revista Cantareira (UFF), Niterói, v. I, n.I, p. 1-23, 2003.

NOTAS. A Republica, Natal, 02 jun. 1909, p. 1.

QUELUZ, Gilson Leandro. Concepções de ensino técnico na República Velha, 1909-1930. Curitiba: Cefet-PR. 2000.

SANTOS, R. M. B. Natal, outra cidade!: o papel da Intendência Municipal no desenvolvimento de uma nova ordem urbana na cidade de Natal (1904-1929). Natal: EDUFRN, 2018.

SILVA, L. O. Terras devolutas e latifúndios. Campinas: Ed. Unicamp, 2008.

SOBREIRA, I. de S. 2008. 100 f. A participação política do analfabeto na democracia brasileira. Dissertação (mestrado em Direito Constitucional). Universidade de Fortaleza, Fortaleza, 2008.

TOLEDO, P. de. Relatório apresentado ao Presidente da República dos Estados Unidos do Brazil pelo Ministro de Estado dos Negocios da Agricultura, Industria e Commercio, no anno de 1911. Disponível em: http://brazil.crl.edu/bsd/bsd/u2001/. Acesso em: 07 dez. 2016.

VIEIRA, M. E. de Q. Relatório apresentado ao presidente da República dos Estados Unidos do Brazil pelo Dr. Manoel Edwiges de Queiroz Vieira, Ministro de Estado da Agricultura, Industria e Commercio, no anno de 1914, 1914. Disponível em: http://brazil.crl.edu/bsd/bsd/u2006/. Acesso em: 01 jan. 2016. 